\title{
POTENSI CENDAWAN ASAL TANAH PERAKARAN BAMBU SEBAGAI ENDOFIT DAN AGEN BIOKONTROL PENYAKIT AKAR GADA PADA TANAMAN BROKOLI
}

\author{
Asniah $^{1}$, Widodo $^{2}$, \& Suryo Wiyono ${ }^{2}$ \\ ${ }^{1}$ Jurusan Agroteknologi Fakultas Pertanian Universitas Haluoleo Kendari \\ Jl. H.A.E Mokodompit Kampus Bumi Tridharma Anduonohu Kendari, 93232. \\ E-mail:asniah_ani@yahoo.com \\ ${ }^{2}$ Departemen Proteksi Tanaman, Fakultas Pertanian, Institut Pertanian Bogor, Bogor
}

\begin{abstract}
The potential of fungi from bamboo rhizosphic soils as endophytic and biocontrol agents of clubroot disease (Plasmodiophora brassicae) on Brocoli. Clubroot, caused by Plasmodiophora brassicae is a serious soilborne disease of plants worldwide, capable of severe infection on broccoli, cabbage and cauliflower. Clubroot is the most destructive diseases on cruciferae in Indonesia. The existing control measures, including biological control do not provide satisfactory result. The objective of the study was to explore fungi from bamboo rhizospheric soils as endophytic that can suppress clubroot disease in broccoli. There were two steps in this study: (1) exploration and identification of fungi from bamboo rhizospheric soils. (2) Effectiveness test of the fungi in suppressing clubroot disease. There were four species of fungi as endophytes in brocoli in this study, e.g Aspergillus sp., Mortierella sp., Paecilomyces sp., and Chaetomium globosum. They had colonized broccoli root endophytically and suppressing clubroot disease. Paecilomyces sp. of endophytic fungi can suppress clubroot diseases incidence for $18.75 \%$.
\end{abstract}

Key words: broccoli, clubroot, root endophytic fungus, bamboo rhizospheric soils

\begin{abstract}
ABSTRAK
Potensi cendawan asal tanah perakaran bambu sebagai endofit dan agen biokontrol penyakit akar gada pada tanaman brokoli. Akar gada, disebabkan oleh Plasmodiophora brassicae adalah salah satu penyakit tular tanah yang penting pada tanaman di seluruh dunia, mampu menimbulkan infeksi pada tanaman brokoli, kubis dan kembang kol. Akar gada adalah penyakit yang paling merusak pada tanaman famili cruciferae di Indonesia. Teknik-teknik pengendalian yang ada, termasuk pengendalian biologis tidak memberikan hasil yang memuaskan. Tujuan dari penelitian ini adalah untuk mengeksplorasi cendawan dari tanah perakaran bambu yang dapat sebagai endofit dan menekan penyakit akar gada pada tanaman brokoli. Ada dua tahap yang dilakukan dalam penelitian ini, yakni (1) eksplorasi dan identifikasi cendawan dari tanah perakaran bambu. (2) Uji efektivitas cendawan dalam menekan penyakit akar gada. Terdapat empat jenis cendawan yang diidentifikasi dalam penelitian ini dapat sebagai endofit pada tanaman brokoli, yaitu: Aspergillus sp., Mortierella sp., Paecilomyces sp., dan Chaetomium globosum yang mengkolonisasi perakaran brokoli secara endofitik dan menekan penyakit akar gada. Cendawan endofit Paecilomyces sp dapat menekan kejadian penyakit akar gada sebesar 18,75\%.
\end{abstract}

Kata kunci: akar gada, brokoli, cendawan endofit akar, tanah perakaran bambu

\section{PENDAHULUAN}

Budidaya brokoli banyak kendala yang dihadapi terutama adanya gangguan dari organisme pengganggu tanaman (OPT), dan salah satu penyakit utama yang menyerang tanaman brokoli adalah akar gada. Akar gada disebabkan oleh Plasmodiophora brassicae, merupakan salah satu kendala utama produksi tanaman kubis di berbagai negara, karena tanaman yang terinfeksi akan terhambat pertumbuhannya dan pada tanaman kubis menyebabkan tanaman tidak dapat menghasilkan
(Agrios, 2005). Kerugian hasil yang diakibatkan oleh penyakit ini berkisar 35 hingga 100 persen (Suryaningsih, 1981). Akar gada pertama kali diketahui di Indonesia pada tahun 1950 di Sukabumi, Jawa Barat. Selanjutnya penyakit akar gada telah menyerang seluruh daerah pertanaman kubis di daerah Jawa Barat. Sampai saat ini penyakit akar gada masih sulit diatasi karena tingginya daya tahan spora rehat $P$. brassicae di dalam tanah. Spora-spora rehat yang terlepas dari serpihan-serpihan akar yang terinfeksi menyebabkan peningkatan inokulum pada areal yang ditanami secara berulang-ulang dengan 
kelompok Brassica spp. P. brassicae merupakan endoparasit obligat dan hanya dapat berkembang pada inang yang terbatas. Jika tanah telah terinfestasi $P$. brassicae maka patogen tersebut akan terus menjadi faktor pembatas pada tanaman famili Brassicaceae, karena daya tahannya yang tinggi terhadap perubahan lingkungan dan pestisida dalam tanah. Sifatnya yang endoparasit obligat ini sering menimbulkan kesulitan dalam mempelajari segi-segi ekologi patogen sehingga beberapa informasi tentang patogen ini belum terpecahkan (Alexopoulos et al., 1996).

Berbagai upaya pengendalian terhadap penyakit akar gada telah banyak dilakukan diberbagai daerah, namun hasil yang diperoleh masih sangat beragam dan belum memuaskan baik secara teknis maupun ekonomis. Beberapa penelitian mengenai pengendalian terhadap penyakit akar gada yang telah dilakukan diantaranya penambahan tepung kitin dan ekstrak pengomposan (Hidayah, 2004), penggunaan bakteri Pseudomonas kelompok fluorescens (Widodo, 1993), penggunaan cendawan endofit akar Heteroconium chaetospira (Narisawa et al., 2000), penggunaan cendawan Mortierella sp. dan Trichoderma spp., dan penggunaan cendawan Phoma glomerata (Arie et al., 1998) akan tetapi belum menunjukkan hasil yang efektif. Upaya pengendalian terhadap penyakit tanaman saat ini lebih banyak diarahkan ke pengendalian hayati. Pengendalian hayati dapat terjadi secara alami maupun melalui manipulasi lingkungan, inang, atau agen antagonis dengan introduksi massal satu jenis antagonis atau lebih. Pengendalian hayati yang saat ini sedang banyak dilakukan adalah penggunaan atau introduksi mikroba endofit baik itu dari golongan cendawan maupun bakteri.

Eksplorasi cendawan dapat dilakukan pada semua bagian tanaman dan tanah sekitar tanaman, juga tanah sekitar perakaran bambu. Tanah perakaran bambu banyak digunakan oleh petani sebagai media persemaian atau pembibitan diduga karena kaya mikroba yang berpeluang sebagai endofit pada tanaman budidaya. Campuran tanah dan serasah daun bambu digunakan sebagai media tanam dalam budidaya anggrek (Anonim, 2006).

Eksplorasi cendawan endofit telah banyak dilakukan pada daerah subtropis terutama untuk tanaman rumput-rumputan, akan tetapi informasi tentang cendawan endofit di daerah tropis dan untuk tanaman pertanian masih sangat terbatas (Azevedo et al., 2000). Untuk itu perlu dilakukan eksplorasi cendawancendawan asal tanah perakaran bambu yang berpotensi menjadi endofit pada tanaman brokoli dan mampu mengendalikan penyakit akar gada.
Penelitian ini bertujuan mendapatkan jenis-jenis cendawan asal tanah perakaran bambu yang dapat menjadi endofit dan menekan penyakit akar gada yang disebabkan oleh $P$. brassicae pada tanaman brokoli pada media tanah yang disterilkan dan tidak disterilkan.

\section{METODE PENELITIAN}

\section{Isolasi Cendawan Asal Tanah Perakaran Bambu.}

Tanah perakaran bambu banyak digunakan petani sebagai media pesemaian. Cendawan secara umum dapat bersifat soilborne yakni dapat bertahan hidup pada tanah. Adapun metode yang dilakukan dimulai dengan memasukkan $10 \mathrm{~g}$ tanah dalam $90 \mathrm{ml}$ akuades steril kemudian digojog pada $200 \mathrm{rpm}$ selama 1 jam. Suspensi tanah ini kemudian diambil $1 \mathrm{ml}$ dan dimasukkan ke dalam $9 \mathrm{ml}$ akuades lalu digojog hingga homogen dengan menggunakan stirer, ini disebut dengan pengenceran $10^{-1}$, selanjutnya diambil $1 \mathrm{ml}$ dari pengenceran $10^{-1}$ dan dimasukkan kedalam $9 \mathrm{ml}$ akuades steril lalu distirer sehingga menjadi pengenceran $10^{-2}$, begitu seterusnya hingga pengenceran $10^{-4}$. untuk isolasi cendawan pada pengenceran $10^{-3}$ dan $10^{-4}$ diambil 0,1 $\mathrm{ml}$ dan disebar pada medium potato dextrosa agar (PDA). Untuk menghindarkan pertumbuhan atau kontaminan dengan bakteri maka media PDA ditambahkan asam laktat $0,1 \mathrm{ml}$ untuk setiap cawan petri media PDA. Cendawan yang tumbuh, diisolasi dan dimurnikan pada medium PDA. Selanjutnya medium yang telah disebar diinkubasi pada suhu ruang dalam inkubator selama tiga hari. Isolat yang tumbuh diisolasi kembali dan dimurnikan pada medium PDA untuk dilakukan identifikasi dan perlakuan selanjutnya.

Setelah 3-7 hari, cendawan yang tumbuh dipindahkan pada media PDA lainnya untuk pemurnian dan identifikasi menggunakan kunci identifikasi Alexopoulos et al. (1996) dan Watanabe (2002).

\section{Pengujian Perkecambahan Benih Brokoli pada} Kultur Cendawan. Benih-benih brokoli dikecambahkan pada media PDA yang berisi isolat cendawan asal tanah perakaran bambu yang telah murni dan pertumbuhan koloninya telah memenuhi permukaan cawan petri (umur biakan 10 hari). Sebagai kontrol, benih dikecambahkan pada media PDA tanpa isolat cendawan. Setiap cawan petri yang berisi isolat cendawan ditumbuhkan 10 benih brokoli dan masing-masing isolat terdiri atas 2 cawan petri. Setelah 5-10 hari dihitung persentase benih-benih yang berkecambah dari setiap isolat, benih berkecambah ditandai dengan terbentuknya akar yang diikuti dengan pertumbuhan daun. 


\section{Pengujian Kolonisasi Cendawan dalam Jaringan}

Akar. Percobaan kolonisasi cendawan asal tanah perakaran bambu dalam jaringan akar brokoli bertujuan untuk mengetahui cendawan-cendawan yang berpotensi sebagai endofit pada tanaman brokoli. Pengujian tersebut dilakukan dengan cara pengamatan infeksi akar oleh cendawan dengan pewarnaan jaringan. Pewarnaan tersebut dilakukan dengan cara: akar-akar tanaman brokoli yang berumur 30 hari di persemaian dibersihkan dari tanah dan dicuci dengan akuades steril sebanyak 3 kali, dan kemudian akar tersebut dipotong-potong kirakira $2 \mathrm{~cm}$. Potongan-potongan akar tersebut selanjutnya dimasukkan dalam larutan pewarna $0,005 \%$ cotton blue dalam 50\% asam asetat. Sebanyak 10 potongan akar tersebut dipilih secara acak dari tiap tanaman dalam setiap perlakuan dan diletakkan pada kaca obyek. Koloni cendawan endofit pada akar tanaman brokoli diamati dibawah mikroskop stereo (Narisawa et al., 2000; Narisawa et al., 1998).

\section{Pengujian Cendawan Endofit dalam Menekan}

Penyakit Akar Gada. Cendawan endofit yang efektif selanjutnya diuji terhadap patogen $P$. brassicae. Cendawan endofit yang diaplikasikan adalah konidia (spora) yang dihitung kepadatan sporanya menggunakan haemasitometer. Aplikasi cendawan endofit dilakukan saat persemaian dengan kepadatan $10^{5} \mathrm{spora} / \mathrm{ml} / \mathrm{g}$ berat kering tanah. Benih brokoli disemaikan selama 35 hari dan selanjutnya dipindahkan pada media tumbuh pada polibag yang lebih besar $($ diameter $=20 \mathrm{~cm})$ dan telah diinokulasi oleh inokulum $P$. brassicae sebanyak $10^{6}$ spora $/ \mathrm{ml} / \mathrm{g}$ berat kering tanah. Rancangan percobaan yang digunakan adalah rancangan acak lengkap, yakni terdiri dari 4 ulangan dan masing-masing ulangan terdiri dari 4 unit tanaman. Pengamatan dilakukan saat panen adalah menghitung persentase kejadian penyakit (\%), indeks penyakit (\%), dan bobot basah tajuk tanaman (g).

Penyiapan Media Semai dan Inokulum $P$. brassicae. Medium tanam yang digunakan dalam penelitian ini adalah media tanam yang mengandung kompos yang berasal dari sekitar kampus IPB Darmaga dengan jenis tanah andosol, dicampur pupuk kandang dengan nisbah 1:1 (v/v). Campuran tanah dan pupuk kandang tersebut dimasukkan dalam polibag $(\varnothing=10 \mathrm{~cm})$ sebagai medium pembibitan. Untuk perlakuan penggunaan media tanam steril, campuran tanah dan pupuk kandang disterilkan dengan cara sterilisasi uap panas pada suhu $121{ }^{\circ} \mathrm{C}$ dan tekanan $1 \mathrm{~atm}$ selama 15 menit.

Inokulum $P$. brassicae diperoleh dengan mengumpulkan akar segar brokoli atau tanaman jenis
Brassicaceae yang bergejala dari daerah pertanaman Brassicaceae. Akar-akar tersebut terlebih dahulu di cuci pada air mengalir untuk menghilangkan sisa-sisa tanah sampai bersih, selanjutnya akar dihancurkan dengan cara diblender kemudian disaring menggunakan kain saring. Hasil saringan selanjutnya disentrifugasi dengan alat sentrifus (International Clinical Centrifuge CL $2628 \mathrm{M}$ 1, Fisher Scientific Co.) pada kecepatan 2000 rpm (700 g) selama 5 menit. Cairan hasil sentrifus diambil dan endapannya dibuang, kemudian kepadatan spora rehatnya dihitung dengan haemasitometer. Suspensi spora tersebut kemudian dicampurkan ke dalam tanah yang telah disiapkan dengan kepadatan $10^{6} \mathrm{spora} / \mathrm{ml} / \mathrm{g}$ berat kering tanah dan diaduk secara merata. Selanjutnya di inokulasi secara buatan dengan suspensi spora $P$. brassicae sebagai medium tanam bersamaan dengan pindah tanam dari pembibitan.

Pemeliharaan Tanaman. Kegiatan Pemeliharaan tanaman meliputi penyiraman, pemupukan, dan pengendalian hama. Penyiraman dilakukan setiap hari selama berlangsungnya penelitian. Pemupukan dilakukan pada saat tanaman berumur 7, 14, dan 21 hari setelah tanam (HST) dengan memberikan pupuk NPK 15:15:15 sebanyak $1 \mathrm{~g} /$ tanaman. Pengendalian hama dilakukan secara mekanik, yakni mengambil hama yang terdapat pada tanaman dengan menggunakan tangan.

Pengamatan. Peubah yang diamati adalah sebagai berikut:

1. Kejadian Penyakit

Kejadian penyakit diamati pada saat panen dengan cara mencatat tanaman yang menunjukkan gejala pembengkakan pada akar tiap satuan percobaan. Selanjutnya kejadian penyakit dihitung dengan menggunakan rumus:

$$
K P=\frac{n}{N} x 100 \%
$$

$K P=$ Kejadian Penyakit

$n=$ jumlah tanaman menunjukkan pembengkakan,

$N=$ jumlah tanaman yang diamati.

\section{Indeks penyakit}

Indeks penyakit diamati pada saat panen dan dihitung dengan nilai skoring berdasarkan metode Narisawa et al. (2000) dengan kriteria sebagai berikut: $0=$ tidak ada pembengkakan,

$1=$ pembengkakan sedikit, pada bagian akar lateral,

$2=$ pembengkakan sedang pada akar lateral dan atau akar utama, 
$3=$ pembengkakan berat pada akar lateral dan atau akar utama,

$4=$ pembengkakan berat dan atau pembusukan pada akar lateral dan atau akar utama.

\section{Bobot basah tanaman tanpa akar}

Bobot basah tanaman (g) tanpa akar diamati pada saat panen dengan cara menimbang bagian tanaman yang ada di atas permukaan tanah.

\section{Tinggi Tanaman}

Tinggi tanaman $(\mathrm{cm})$ pada saat panen dengan cara mengukur tinggi tanaman $2 \mathrm{~cm}$ dari pangkal batang di atas permukaan tanah sampai pada pucuk termuda.

\section{Diameter Batang Tanaman}

Diameter batang tanaman $(\mathrm{cm})$ diamati pada saat panen dengan cara mengukur diameter batang pada pangkal batang dengan menggunakan jangka sorong.

Analisis Data. Data yang diperoleh dianalisis dengan menggunakan program Statistical Analysis System (SAS) versi 9.1. Pengaruh perlakuan dianalisi dengan sidik ragam. Apabila terdapat beda nyata antar perlakuan dilakukan uji lanjut dengan uji jarak berganda Duncan pada taraf nyata 5\%. Data non parametrik diuji dengan menggunakan uji non parametrik Chi-Square.

\section{HASIL DAN PEMBAHASAN}

Cendawan yang terpilih dan berpotensi sebagai cendawan endofit dari seluruh hasil isolasi dari tanah perakaran bambu berjumlah empat isolat. Selanjutnya isolat yang terpilih dan berpotensi sebagai cendawan endofit digunakan dalam pengujian terhadap penyakit akar gada. Dalam seleksi cendawan endofit terpilih pengamatan dilakukan berdasarkan frekuensi akar terinfeksi dengan cara re-isolasi dan pewarnaan yang diamati pada 30 hari setelah semai. Dengan cara re- isolasi, tanaman yang diberi perlakuan dengan cendawan endofit Paecilomyces sp. menunjukkan frekuensi akar terinfeksi tertinggi yakni, $60 \%$ dan terendah ditunjukkan pada tanaman yang diberi perlakuan cendawan endofit Aspergillus sp. dan Mortierella sp., yakni masingmasing $10 \%$. Sedangkan dengan cara pewarnaan akar, cendawan endofit Chaetomium globosum menunjukkan kemampuan infeksi akar tertinggi yakni $79 \%$ sedangkan terendah ditunjukan oleh cendawan endofit Mortierella sp. 49\% (Tabel 1).

Inokulasi dengan cendawan Paecilomyces sp. memberikan kejadian penyakit akar gada yang nyata lebih rendah yakni 81,25\% dibandingkan dengan kontrol, meskipun tidak berbeda nyata dengan perlakuan lainnya (Tabel 2). Perlakuan media semai tidak memberikan pengaruh yang nyata terhadap kejadian penyakit, perlakuan media semai yang disterilkan maupun yang tidak disterilkan adalah sama, yakni 88,75\% (Tabel 2).

Berdasarkan uji nonparametrik chi-square diketahui bahwa secara umum perlakuan jenis cendawan endofit asal tanah perakaran bambu berpengaruh nyata pada indeks penyakit akar gada $(P=0,05)$. Indeks penyakit terendah yakni 1,03 terjadi pada tanaman yang diberi perlakuan cendawan endofit Paecilomyces sp., sedangkan indeks penyakit tertinggi yakni 2,56 terjadi pada perlakuan kontrol (Gambar 1). Selanjutnya perlakuan media semai juga berpengaruh nyata terhadap indeks penyakit akar gada, indeks penyakit terendah adalah pada perlakuan dengan menggunakan media semai yang tidak disterilkan yakni 1,34 .

Gejala pembengkakan akar yang disebabkan oleh patogen bervariasi terhadap berbagai perlakuan cendawan endofit asal tanah perakaran bambu (Gambar 2).

Perlakuan cendawan endofit Paecilomyces sp. memberikan bobot basah tanaman yang tertinggi yakni $49,38 \mathrm{~g}$ dibandingkan kontrol yakni 32,59g. Perlakuan antara jenis cendawan endofit tidak berbeda nyata

Tabel 1. Rataan frekuensi akar terinfeksi pada tanaman brokoli yang diinokulasi cendawan endofit asal tanah perakaran bambu pada umur 30 hari setelah semai

Frekuensi akar terinfeksi (\%)

Perlakuan
Re-isolasi
Pewarnaan akar

$\begin{array}{lcc}\text { Kontrol } & 0 & 27 \\ \text { Chaetomium globosum } & 40 & 79 \\ \text { Paecilomyces sp. } & 60 & 76 \\ \text { Aspergillus sp. } & 10 & 66 \\ \text { Mortierella } \text { sp. } & 10 & 49\end{array}$


Tabel 2. Rataan kejadian penyakit (\%) dan Bobot basah tajuk (g) terhadap perlakuan cendawan endofit asal tanah perakaran bambu dan perlakuan media semai pada tanaman brokoli

\begin{tabular}{|c|c|c|}
\hline Perlakuan & Kejadian penyakit (\%) & Bobot basah tajuk (g) \\
\hline \multicolumn{3}{|l|}{ Jenis Cendawan Endofit } \\
\hline Kontrol & $100 \pm 0$ & $32,59 \pm 8,29$ \\
\hline Chaetomium globosum & $84,38 \pm 18,60 a b$ & $46,57 \pm 14,39 a b$ \\
\hline Paecilomyces sp. & $81,25 \pm 17,68 \quad b$ & $49,38 \pm 10,57 \mathrm{a}$ \\
\hline Aspergillus sp. & $87,50 \pm 13,36 \mathrm{ab}$ & $44,23 \pm 14,25 \mathrm{ab}$ \\
\hline Mortierella sp & $90,63 \pm 12,94 \mathrm{ab}$ & $38,41 \pm 8,94 \quad b c$ \\
\hline \multicolumn{3}{|l|}{ Media Semai } \\
\hline Disterilkan & $88,75 \pm 15,12 a$ & $37,79 \pm 9,31 \quad b$ \\
\hline Tidak Disterilkan & $88,75 \pm 15,12$ a & $48,16 \pm 12,37 \mathrm{a}$ \\
\hline
\end{tabular}

Angka yang diikuti oleh huruf yang sama pada setiap faktor tunggal tidak berbeda nyata berdasarkan uji jarak berganda Duncan pada taraf nyata $5 \%$.

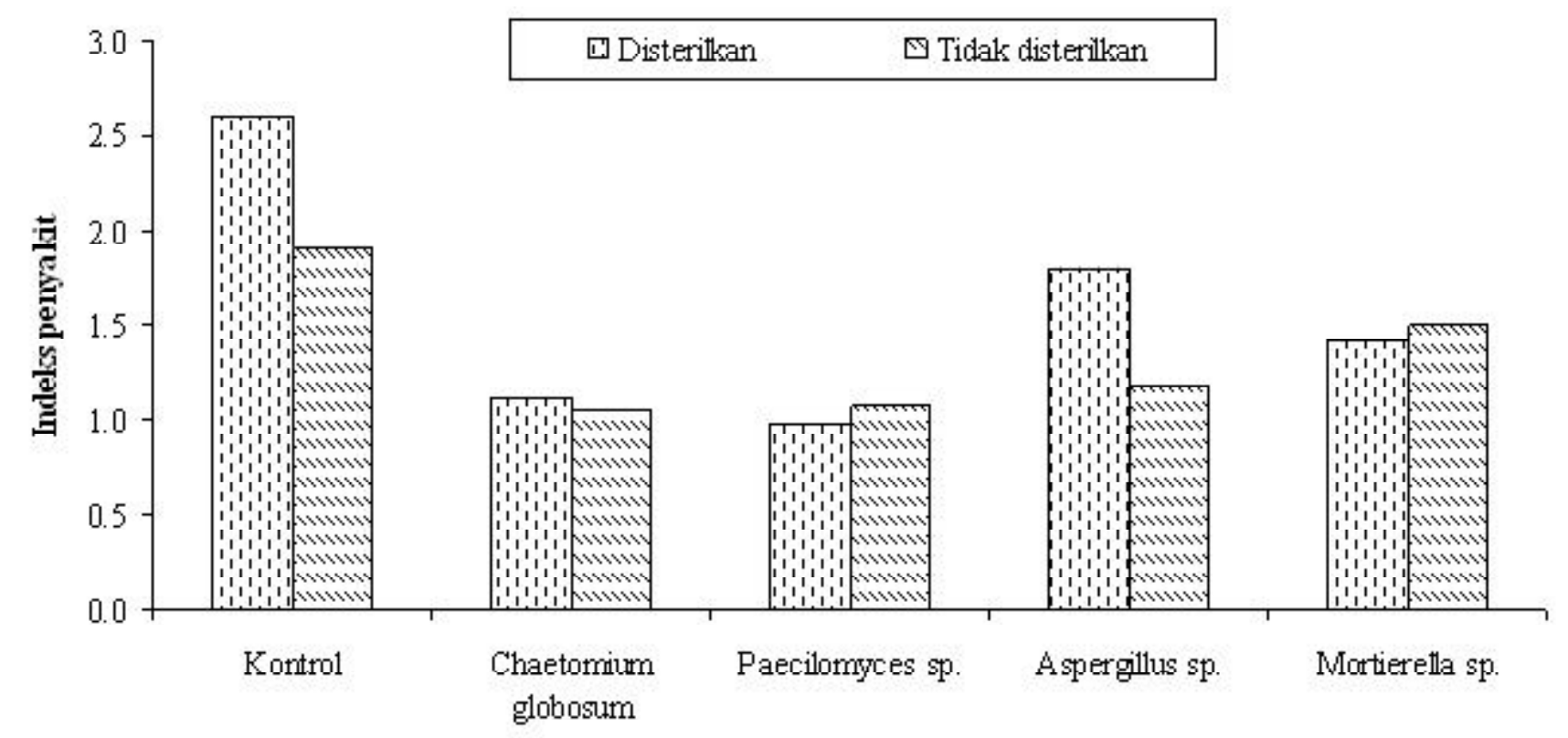

\section{Cendawan endofit}

Gambar 1. Indeks penyakit akar gada pada berbagai jenis cendawan endofit asal tanah perakaran bambu dan media semai.

terhadap bobot basah tanaman, dan media semai berpengaruh nyata terhadap bobot basah tanaman, media semai yang tidak disterilkan menunjukkan bobot basah tanaman tertinggi 37,79 g dibandingkan dengan media semai yang disterilkan (Tabel 2).

Pada pengamatan tinggi tanaman, perlakuan dengan cendawan endofit Paecilomyces sp. dan $C$. globosum berpengaruh nyata terhadap tinggi tanaman brokoli yakni masing-masing 21,58 cm dan $20,18 \mathrm{~cm}$ dibandingkan dengan kontrol dan cendawan endofit Aspergillus sp. dan Mortierella sp. Perlakuan media semai berpengaruh nyata pada tinggi tanaman, perlakuan dengan media semai yang tidak disterilkan lebih tinggi dibandingkan dengan media semai yang disterilkan (Tabel 3). Perlakuan dengan cendawan endofit Paecilomyces sp., C. globosum, dan Aspergillus sp. memberikan pengaruh nyata terhadap diameter batang tanaman, yakni masing-masing $21,58 \mathrm{~cm} ; 20,18 \mathrm{~cm}$ dan $17,76 \mathrm{~cm}$ lebih tinggi dibandingkan dengan kontrol yakni $16,97 \mathrm{~cm}$ meskipun tidak berbeda nyata dengan perlakuan cendawan endofit Mortierella sp. Perlakuan media semai yang disterilkan berpengaruh nyata terhadap diameter batang tanaman tertinggi dibanding dengan media semai yang tidak disterilkan (Tabel 3). 

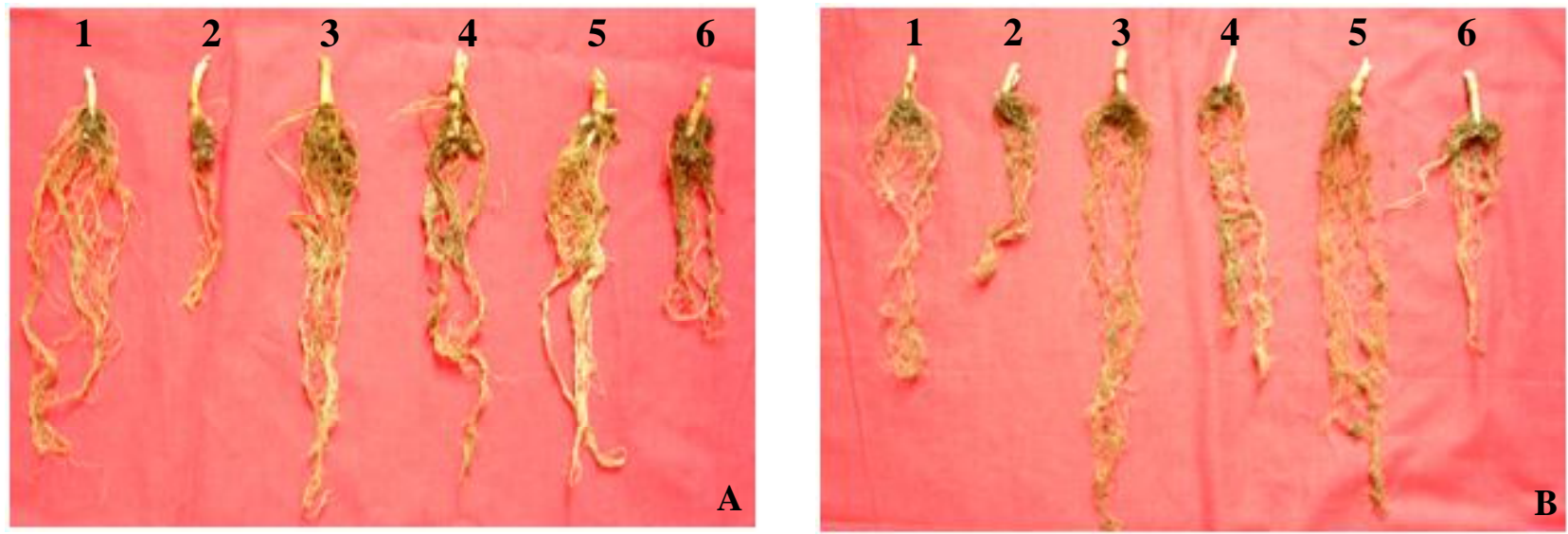

Gambar 2. Gambar gejala penyakit akar gada di akar pada perlakuan cendawan endofit asal tanah perakaran bambu. 1 (kontrol, dimana tanpa inokulasi patogen atau endofit), 2 (inokulasi patogen tanpa inokulasi endofit), 3 (C. globosum), 4 (Paecilomyces sp.), dan 5 (Aspergillus sp.), 6 (Mortierella sp.). A (media semai yang disterilkan) dan B (media tidak disterilkan.

Tabel 3. Rataan tinggi tanaman $(\mathrm{cm})$ dan diameter batang $(\mathrm{g})$ terhadap perlakuan cendawan endofit asal tanah perakaran bambu dan perlakuan media semai pada tanaman brokoli

\begin{tabular}{lcc}
\hline Perlakuan & Tinggi tanaman $(\mathrm{cm})$ & Diameter batang $(\mathrm{cm})$ \\
\hline Jenis Cendawan Endofit & $16,97 \pm 1,94 \mathrm{~b}$ & \\
Kontrol & $20,18 \pm 1,97 \mathrm{a}$ & $0,45 \pm 0,045 \mathrm{~b}$ \\
Chaetomium globosum & $21,58 \pm 1,94 \mathrm{a}$ & $0,52 \pm 0,048 \mathrm{a}$ \\
Paecilomyces sp. & $17,76 \pm 1,94 \mathrm{~b}$ & $0,53 \pm 0,073 \mathrm{a}$ \\
Aspergillus sp. & $17,99 \pm 0,86 \mathrm{~b}$ & $0,51 \pm 0,082 \mathrm{a}$ \\
Mortierella sp & $18,05 \pm 2,11 \mathrm{~b}$ & $0,45 \pm 0,074 \mathrm{~b}$ \\
Media Semai & $20,22 \pm 2,18 \mathrm{a}$ & $0,53 \pm 0,054 \mathrm{a}$ \\
Disterilkan & & $0,47 \pm 0,075 \mathrm{~b}$ \\
Tidak Disterilkan &
\end{tabular}

Angka yang diikuti oleh huruf yang sama pada setiap faktor tunggal tidak berbeda nyata berdasarkan uji jak berganda Duncan pada taraf nyata 5\%.

Pengendalian hayati dapat memberikan perlindungan selama siklus hidup tanaman (Copeland \& McDonald, 1995). Pengendalian hayati juga dilaporkan dapat memacu peningkatan pertumbuhan tanaman yang pada akhirnya meningkatkan hasil tanaman sebagai akibat dari pengendalian penyakit jangka panjang (Zhang et al., 2002; Silva et al., 2004; Yan et al., 2004). Aktivitas agen biokontrol di lapangan dipengaruhi oleh kondisi lingkungan ( $\mathrm{pH}$, suhu, kelembapan) dan interaksi dengan mikroorganisme lain (Timmusk, 2003). Dalam hubungan dengan pengendalian terhadap patogen, efektivitas agen biokontrol sangat dipengaruhi oleh cara aplikasi agen biokontrol, dosis inokulasi dan kontrol mikroba lain. Hal lain yang dapat meningkatkan efektivitas perlakuan benih dengan agen biokontrol adalah nutrisi bagi mikroba dan kecepatan mikroba menyesuaikan diri. Tak kalah penting adalah sterilisasi permukaan benih dengan natrium hipoklorit sebelum aplikasi dengan agen biokontrol. Hal ini untuk menghindari patogen lain yang dapat berkompetisi dengan agen biokontrol (Copeland \& McDonald, 1995).

Aplikasi cendawan endofit C. globosum memberikan pengaruh yang baik dalam mengendalikan penyakit akar gada pada tanaman brokoli. Ini dikarenakan C. globosum diduga menghasilkan senyawa metabolik sekunder. Salah satu senyawa metabolik sekunder yang dihasilkan oleh Chaetomium spp. adalah antibiotik. Hasil penelitian Cullen \& Andrews (1984) dalam Hasanuddin (2003) bahwa, antibiotik chetomin yang dihasilkan secara in vitro oleh $C$. globosum berkorelasi positif dengan antagonisnya terhadap Venturia inequalis pada bibit pohon apel. Firakova et al. (2007) 
mengatakan bahwa, cendawan endofit dapat berfungsi sebagai pensintesis senyawa kimia di dalam jaringan tanaman.

\section{SIMPULAN}

Berdasarkan hasil penelitian dan pembahasan terdapat 4 jenis cendawan asal tanah perakaran bambu yang dapet menjadi endofit pada tanaman brokoli dan dapat mengendalikan penyakit akar gada pada tanaman brokoli, yakni Chaetomium globosum, Aspergillus sp., Paecilomyces sp., dan Mortierella sp. Cendawan endofit Paecilomyces sp. mampu menekan kejadian penyakit akar gada $18,75 \%$ dan meningkatkan pertumbuhan tanaman brokoli dibandingkan dengan cendawan endofit lainnya dan tanpa cendawan endofit.

\section{SANWACANA}

Ucapan terima kasih kepada DIKTI yang telah memberikan beasiswa program pascasarjana (BPPS), yang membantu sebagian pembiayaan penelitian ini.

\section{DAFTAR PUSTAKA}

Agrios GN. 2005. Plant Pathology. $5^{\text {th }} \mathrm{ed}$. Academic Press. New York.

Anonim. 2006. Varietas anggrek Spathoglottis yang menawan. Warta Penelitian dan Pengembangan Pertanian 28(3):16-17.

Alexopoulos CJ, Mims CW, \& Blackwell M. 1996. Introductory Mycology. $4^{\text {th }}$ ed. John Wiley and Sons. New York.

Arie T, Kobayashi Y, Okada G, Kono Y, Yamaguchi I. 1998. Control of soilborne clubroot disease of cruciferous plant by epoxydon from Phoma glomerata. Plant Dis. 47:743-748.

Azevedo JL, Maccheroni JR, Pereira JO, Araujo WL. 2000. Endophytic microorganism: a review in insect control and recent advances on tropical plants. J Biotechnol. 3(1):40-66.

Copeland LO \& McDonald MB. 1995. Principles of Seed Science and Technology. Third Edition. New York: ChapmAnd \& Hall.

Firakova S, Sturdikova M, \& Muckova M. 2007. Bioactive secondary metabolites produced by mikroorganisms associated with plants. J. Biol Bratisl. 62(3):251-257.
Hasanuddin. 2003. Peningkatan peranan mikroorganisme dalam sistem pengendalian penyakit tumbuhan secara terpadu. Medan: Jurusan Hama dan Penyakit Tumbuhan, Fakultas Pertanian, Universitas Sumatera Utara. USU digital library. http://library.usu.ac.id/download/ fp/fp-hasanuddin.pdf. [8 September 2007].

Hidayah N. 2004. Penggunaan Tepung Kulit Rajungan sebagai Sumber Kitin dan Ekstrak Kompos untuk Pengendalian Penyakit Akar Gada [tesis]. Bogor: Fakultas Pertanian, Institut Pertanian Bogor.

Istikorini Y. 2008. Potensi Cendawan Endofit untuk Mengendalikan Penyakit Antraknosa pada Cabai (Capsicum annuum L.) [Disertasi]. Bogor: Fakultas Pertanian, Institut Pertanian Bogor.

Narisawa K, Tokumasu S, \& Hashiba T. 1998. Suppresion of clubroot formation in Chinese cabbage by the root endophytic fungus, Heteroconium chaetospira. J. Plant Pathol. 47:206-210.

Narisawa K, Ohki KT, \& Hashiba T. 2000. Suppresion of clubroot and verticillium yellows in chinese cabbage in the field by root endophytic fungus, Heteroconium chaetospira. J. Plant Pathol. 49:141-146.

Silva HSA, Romeiro RSR, Macagnan D, Vieira BAH, Pereira MCB, \& Mounteer A. 2004. Rhizobacterial induction of systemic resistance in tomato plants: non-specific protection and increase in enzyme activities. Biol. Control. 29:288-295.

Suryaningsih E. 1981. Penyakit akar pekuk (Plasmodiophora brassicae Wor.) penyebaran dan cara pemberantasannya. Hlm. 1-11 dalam: Prosiding Kongres Nasional VI dan Seminar Ilmiah Perhimpunan Fitopatologi Indonesia; Bukittinggi, 11-13 Mei 1981.

Timmusk S. 2003. Mechanism of actions of the plantgrowth-promoting rhizobacterium Paenibacillus polymixa [Dissertation]. Uppsala, Sweden: Departement of Cell and Molecular Biology, Uppsala University. http://publications.uu.se/uu/ fulltext/nbnseuudiva3773.pdf. [17 November 2007).

Watanabe T. 2002. Pictorial Atlas of Soil and Seed Fungi. Ed ke-2. Washington: CRC Pr. 
Widodo. 1993. Penggunaan Pseudomonas spp. kelompok fluoresen untuk pengendalian penyakit akar gada (Plasmodiophora brassicae Wor.) pada caisin (Brassica campestris L. var. chinensis (RUPR) OLSON) [Tesis]. Bogor: Fakultas Pertanian, IPB.

Yan Z, Ryu CM, McInroy J, Reddy MS, Woods F, Wilson M, \& Kloepper JW. 2004. Induction of systemic resistance against tomato late blight by PGPR. http://www.ag.auburn.edu/argentina/ pdfmanuscripts/yan2.pdf [20 Okt 2006].
Zhang S, Reddy MS, \& Kloepper JW. 2002. Development of assay for assessing induced systemic resistance by plant growth-promoting rhizobacteria against blue mold of tobacco. Biol Control 23:79-86. 